uploads/2016/02/Zarubizhnij-dosvid-uprovadzhennya-elektronnogouryaduvannya.pdf (дата звернення: 10.04.2021).

9. Электронная демократия: граждане и власть. URL: http://imrussia.org/ru/society/330-e-democracy-citizens-and-the-state (дата звернення: 10.04.2021).

10. Системи електронних виборів: процедури голосування та матеріальнотехнічні засоби. Міжнародний досвід. Інформаційна довідка, Європейський інформаційно-дослідницький центр, 10 с. URL: http://euinfocenter.rada.gov.ua/uploads/documents/28966.pdf (дата звернення: 10.04.2021).

11. Прямая демократия Швейцарии в цифровую эпоху URL: http://www.swissinfo.ch/rus/detail/content.html?cid=36670692\&link=ct о (дата звернення: 10.04.2021).

12. Про Концепцію «Запровадження системи електронного голосування в Україні»: проект закону України від 10.06.2011. URL: https://ips.ligazakon.net/document/JF6OG00A (дата звернення: 10.04.2021).

13. В Україні ухвалили новий закон про референдум URL:https://www.dw.com/uk/v-ukraini-ukhvalyly-novyi-zakon-pro-referendum/a-56349619

14. Про народовладдя через всеукраїнський референдум: Закон України від 26.01.2021 № 1135-IX URL:http://w1.c1.rada.gov.ua/pls/ zweb2/webproc4_1?pf3511=69060 (дата звернення: 10.04.2021).

DOI https://doi.org/10.30525/978-9934-26-074-2-34

\title{
HARMONIZATION OF UKRAINIAN LEGISLATION ON VERTICAL CONCERTED ACTIONS WITH THE COMPETITION LEGISLATION OF THE EUROPEAN UNION
}

\author{
Kravtsova I. A. \\ Postgraduate Student at the Department \\ of International Law and Comparative Law \\ National University of Life and Environmental Sciences of Ukraine \\ Kyiv, Ukraine
}

The principle of freedom is the most important principle of law [1]. It is fundamental for determining the scope of human rights and freedoms and it determines the nature of a person's behavior in legal relations [2]. Freedom of contract is one of the principles that belongs to the general principles of civil 
law. However, freedom of competition cannot be unlimited and must be regulated by the state.

The impetus for Ukrainian legislative regulation on vertical concerted actions was the signing of the Association Agreement between Ukraine, on the one part, and the European Union and the European Atomic Energy Community and their Member States, on the other part [3] (hereinafter - the Association Agreement between Ukraine and the EU). Thus, p. 3 of the Article 256 of the Association Agreement between Ukraine and the EU foresees implementation by Ukraine the Articles 1, 2, 3, 4, 6 and 8 of Commission Regulation (EU) No 330/2010 of 20 April 2010 on the application of Article 101(3) of the Treaty on the Functioning of the European Union to the categories of vertical agreements and concerted practices [4] (hereinafter - the Regulation №330/2010). Ukraine has made a commitment to implement the provisions related to the categories of vertical agreements and concerted practices within 3 years of the entry into force of the Association Agreement between Ukraine and the EU.

The task of fulfilling taken obligations was assigned to the Antimonopoly Committee of Ukraine - a state body with a special status, the purpose of which is to ensure state protection of competition in business and public procurement [5].

This state authority holds a special place in the formation, development and protection of economic competition in Ukraine. The Antimonopoly Committee of Ukraine is granted with a number of powers that give it the status of an independent state authority [6]. Thus, the Antimonopoly Committee of Ukraine adopted the Order № 10-pп dated 12 October 2017, that approves the Typical requirements for vertical concerted actions of undertakings regarding the supply and use of goods (hereinafter - the Order № 10-рп) [7]. The legal expression of commitments taken by Ukraine was implemented through typical requirements as, according to the explanatory note of the Antimonopoly Committee of Ukraine to the draft of the Order, «definition of typical requirements for certain categories of concerted actions of undertakings aims to minimize the risks of business entities of being prosecuted for violation of the legislation on protection of economic competition at simultaneous elimination of additional transaction costs and creation of favorable conditions for their economic activity» [8].

Unlike European Union law, Ukrainian legislator did not introduce the term «vertical agreement» but instead introduced the term «vertical concerted actions of undertakings». It should be also clarified that the general definition of «vertical concerted actions of undertakings» currently does not exist in Ukrainian legislation. The definition stipulated in the Order № 10-pп regulates the relations in the field of supply and use of goods. In accordance with the 
Order № 10-рп, vertical concerted actions of undertakings regarding the supply and use of goods are defined as concerted actions involving two or more business entities that operating at different levels of the production chain or supply within such concerted actions, and members that may buy, sell or resell certain goods. It should be noted that prior to the implementation of the Order № 10-pп, the general definition of «vertical concerted actions» was outlined in the Order of the Antimonopoly Committee of Ukraine «On approval of Typical requirements for concerted actions of undertakings for general exemption from prior approval from bodies of the Antimonopoly Committee on concerted actions of undertakings» № 27-p of 12 February 2002 [9] (hereinafter - the Order № 27-p) and was determined as follows: «vertical concerted actions - the conclusion of business entities agreements in any form, the adoption of decisions in any form by associations, any other concerted competitive behavior (activity, inaction) of business entities, the establishment of business entity, its purpose or consequence of establishment is the coordination of competitive behavior between business entities that established the specified business entity, or between them and the newly established business entity, when the business entities, which include participants in the concerted action, do not compete and under existing conditions cannot compete with each other in one market of goods, and are or may be in a relationship of sale in the relevant commodity markets (seller buyer, supplier - consumer)». However, with the adoption of the Order №10рп, the above definition was excluded, amended and transferred to the newly adopted order. We consider that the term defined in the Order №27-p is more complete and reflects the provisions of p. 1 of the Article 101 of the Treaty on the Functioning of the European Union, namely on the described category of agreements «...all agreements between undertakings, decisions by associations of undertakings and concerted practices which may affect trade between Member States...» [10]. On the other hand, the term set out in the Order № 10-pп reflects the definition given in Regulation № 330/2010: «vertical agreement» means an agreement or concerted practice entered into between two or more undertakings each of which operates, for the purposes of the agreement or the concerted practice, at a different level of the production or distribution chain, and relating to the conditions under which the parties may purchase, sell or resell certain goods or services.

The Order № 10-pп clearly outlines the boundaries of permitted vertical concerted actions that do not require the permission of the Antimonopoly Committee of Ukraine to commit them, and vertical concerted actions that are prohibited. In fact, definition of permitted concerted actions, exceptions, the list of vertical restraints that are divided into «hardcore» and «safe harbor» that 
are set in Ukrainian legislation almost totally correspond to those that are set in the Regulation № 330/2010.

As a conclusion, harmonization of European and Ukrainian legislation reflected positively on the revision and update of Ukrainian legislation in the field of protection of economic competition. The formation and development of economic competition depends on the quality of legislative acts [11, p. 154]. The adoption of the Order №10-pп had a positive impact on the activities of business entities in the Ukrainian market, as this legal act defined the permissible actions of business entities, within which they can freely conduct their business activity without violating competition law, and therefore minimize their risks of being prosecuted.

\section{References:}

1. Ladychenko V.V. A comprehensive approach to the principles of law // State and Law: Collection of scientific work. Legal and political sciences. Edition 26. $-\mathrm{K}$.: Inst. Of State and Law n.a. V.M Koretsky NAS of Ukraine, 2004. - p. 73-78.

2. Ladychenko V.V. Interconnection of law and freedom // Legal Ukraine. - 2011. - № 10. - P. 4-9.

3. The Association Agreement between Ukraine, on the one part, and the European Union and the European Atomic Energy Community and their Member States, on the other part. OJ L 161, 29.5.2014, P. 3-2137. URL: https://eur-lex.europa.eu/legal-content/EN/TXT/?uri=OJ:L:2014:161

4. Commission Regulation (EU) No 330/2010 of 20 April 2010 on the application of Article 101(3) of the Treaty on the Functioning of the European Union to the categories of vertical agreements and concerted practices. OJ L 102, 23.4.2010. P. 1-7. URL: https://eur-lex.europa.eu/legal-content/ EN/ALL/?uri=CELEX\%3A32010R0330.

5. On Antimonopoly Committee of Ukraine : Law of Ukraine of 26 November 1993. No 3659-XII. URL: https://zakon.rada.gov.ua/laws/ show/3659-12\#Text.

6. Kravtsova I. Peculiarities of the powers of the Antimonopoly Committee of Ukraine as a subject of state control over the compliance of antimonopoly and competition legislation. Scientific potential and prospects of legal science development : abstracts of reports of the international scientific-practical conference, Zaporizhia, 26-27 March 2021 / General. ed. T.O. Kolomoyets. - Zaporizhia : ZNU, 2021. P. 73-76

7. Typical requirements for vertical concerted actions of undertakings regarding the supply and use of goods : Order of the Antimo- 
nopoly Committee of Ukraine of 12 October 2017 № 10-pп. URL: https://zakon.rada.gov.ua/laws/show/z1364-17\#Text.

8. Explanatory note to the draft of the Order of the Antimonopoly Committee of Ukraine «On approval of the Typical requirements for vertical concerted actions of undertakings regarding the supply and use of goods which observance allows to carry out these concerted actions without the permission of the bodies of the Antimonopoly committee of Ukraine». URL: http://www.amc.gov.ua/amku/doccatalog/document?id=136109

9. Typical requirements for concerted actions of undertakings for general exemption from prior approval from bodies of the Antimonopoly Committee on concerted actions of undertakings : Order of the Antimonopoly Committee of Ukraine of 12 February 2002 №27-p. URL: https://zakon.rada.gov.ua/ laws/show/z0239-02\#Text.

10. The Treaty on the Functioning of the European Union. OJ C 326, 26/10/2012. P. 0001-0390. URL: https://eur-lex.europa.eu/ legal-content/EN/TXT/?uri=CELEX:12012E/TXT.

11. Kravtsova I. Economic competition as an object of administrative regulation. Entrepreneurship, Economy and Law. 2020. №6. P. 149-155. URL: http://pgp-journal.kiev.ua/archive/2020/6/27.pdf

DOI https://doi.org/10.30525/978-9934-26-074-2-35

\title{
ЕЛЕКТРОННІ РАХУНКИ З ПОДАТКУ НА ДОДАНУ ВАРТІСТЬ: ПРОБЛЕМНІ ПИТАННЯ ТА ШЛЯХИ ВИРІШЕННЯ
}

\author{
Логвин А. В. \\ доктор філософії з права
}

Основне завдання системи адміністрування податків полягає у забезпеченні якісного обліку платників податків, повноти та своєчасності надходжень податкових платежів до бюджетної системи згідно 3 вимогами чинного законодавства. При цьому ефективність адміністрування досягається за рахунок ії належного нормативного закріплення та правового підгрунтя відповідних положень.

В свою чергу, головна юридична проблематика податкової сфери полягає переважно у визначенні та ефективному забезпеченні меж свободи й необхідності у поведінці суб'єктів податкових правовідносин через відповідні правові, законодавчі норми, у захисті права власності окремих платників та інтересів суспільства, які реалізуються у фінансово-податковій діяльності держави. 